\title{
THERMAL REGIMEN OF FIRN ON UPPER SEWARD GLACIER, YUKON TERRITORY, CANADA*
}

\author{
By ROBERT P. SHARP \\ (California Institute of Technology, Pasadena, Calif., U.S.A.)
}

\begin{abstract}
Temperatures were measured within the firn and ice of the upper reaches of the Seward Glacier (referred to in this paper as the "upper Seward Glacier") to a depth of $204 \mathrm{ft} .(62 \cdot 2 \mathrm{~m}$.) by means of thermohms and (referred to in this paper as the "upper Seward a feasible means of penetrating this glacier. The winter's chilled layer a Wheatstone bridge. Thermal boring proved a feasible means of penetrating this a thickness of $40-50 \mathrm{ft}$. $\left(12 \cdot 2-15 \cdot 2 \mathrm{~m}\right.$.) and attains temperatures of at least $-\mathrm{I}^{\circ} \mathrm{C}$. Deterioration of the chilled layer is rapid and irregular in the final phase and is attributed largely to freezing of percolating melt of the chilled layer is rapid and in environments with water. Melt water exerts such a powerful influence on thermal regimentestensically temperate because of extensive mean annual temperatures below freezing may, nonetheless, be geophysically temperate because of warming by melt water in summer. In July. The slow development and rapid deterioration of diurnal crusts on firn and the lag effects at depth reproduce in miniature the behavior of the annual chilled layer. On the basis of its thermal regimen the upper Seward Glacier is geophysically temperate.
\end{abstract}

Zusammenfassung. Temperaturen in Firn und Eis in dem oberem Teil des Seward Glacier wurden bis zu . Thermohms " und einer Wheatstoneschen Brücke gemessen. Thermische Bohrungen erwiesen sich als geeignete "Mittel, um in diesen Gletscher einzudringen. Die Frostschicht des Winters Bohrungen erwiesen sich als geeignete 1 Metern und erreicht Temperaturen von mindestens - $13^{\circ} \mathrm{C}$. Der Verfall entwickelt hier eine Dicke von $12 \cdot 2-15 \cdot 2$ Metern und erreicht Temperaturen von mindestens -13 . der Frostschicht geht schnell, in der letzten Phase unregelmässig vor sich und wird hauptsächlich auf das Gefrieren von durchsickerndem Schmelzwasser zurückgeführt. Schmelzwasser übt einen derartig starken Einfuss auf den thermischen Haushalt aus, dass Firnmassen im Bereich von Durchschnittstemperaturen unter Null gemăssigt sein können, weil das Schmelzwasser im Sommer ausserordentlich wärmend wirkt. Sowohl im Jahre 1948 wiengsame 1949 verschwand die Jahresfrostschicht von diesem Gletscher innerhalb der ersten 10 Tage im Juli. Die langsamen Entwicklung und der schnelle Verfall von dem auf Firn gebildeten Tagesharsch und die verzögernden Wirkungen in der Tiefe geben im Kleinen das Verhalten der Jahresfrostschicht wieder. Auf Grund seiner thermischen Reaktion ist dieser Gletscher gemässigt.

\section{THERMAL REGIMEN OF FIRN}

\section{INTRODUCTORY StATEMENT}

Knowledge of thermal regimen within glaciers is essential to their geophysical classification, 1 and to an evaluation and understanding of the processes converting snow to ice. The physical properties and mechanical behavior of snow, firn and ice, and many of the structures developed in firn, are influenced or controlled by temperature relations.

Firn temperatures have been most thoroughly investigated in recent years by the NorwegianSwedish Expedition in West Spitsbergen ${ }^{2}$ and the British Jungfraujoch Research Party in the Alps. ${ }^{3}$ These studies have borne out early calculations and deductions $4 a, b$ to the effect that glaciers are chilled by conduction in winter and warmed by conduction and freezing of descending melt water in summer to a depth of some tens of feet. However, the conclusion that the base of the zone of annual fluctuation has the mean annual temperature of the region, provided this is below $0^{\circ} \mathrm{C}$., is discounted by the modern work which shows that melt water has a much greater influence on thermal regimen than was formerly thought. Furthermore, thermal relations in firn and ice are now known to differ considerably from place to place, ${ }^{5}$ and generalizations are difficult without thorough knowledge of the environment.

Thermal relations within the annual chilled layer are the principal consideration of this report. Some observations of diurnal temperature changes within surface crusts are also reported as they support the general conclusions. Temperature data have aided immeasurably in understanding the origin of structures within the Seward firn and are essential to proper calculation of total accumulation and net ablation.

- Division of Geological Sciences, California Institute of Technology, Contribution Number 543. 


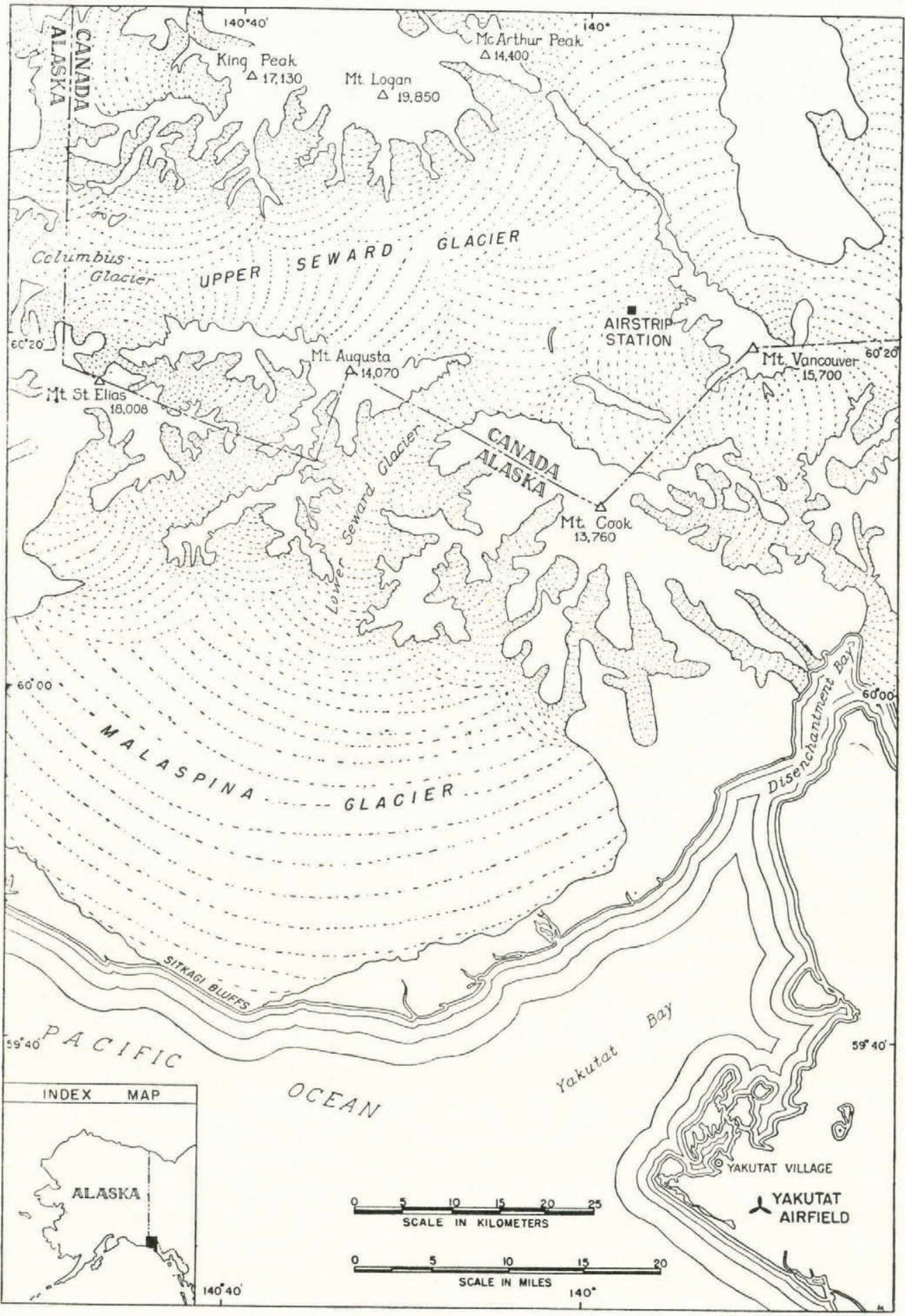

Fig. I. Malaspina-Seward glacier system and environs 


\section{Location and Physical Setting}

Seward Glacier consists of two parts, a large intermontane accumulation basin of approximately 515 square miles $\left(1338 \mathrm{~km} .{ }^{2}\right)$ and a narrow outlet stream, 24 miles $(38.6 \mathrm{~km}$.) long by $3-4$ miles $(4 \cdot 8-6 \cdot 4 \mathrm{~km}$.) wide, discharging with high velocity into the piedmont Malaspina Glacier (Fig. I, p. 477). Attention is focused on the accumulation basin, lying for the most part at elevations between 5000 and $7000 \mathrm{ft}$. (1525-2135 m.) and almost completely encircled by a girdle of high peaks and mountain ridges culminating to the north-west in Mt. Logan, 19,850 ft. (6060 m.).

For purposes of identification, the intermontane glacier ${ }^{6}$ occupying the accumulation basin is referred to in this paper as the upper Seward Glacier in contrast to the outlet ice stream, or lower Seward Glacier. The upper Seward Glacier lies wholly within the Yukon Territory of Canada, just north of the Alaskan boundary (Fig. I). It is situated within the heart of the St. Elias Range approximately 50 airline miles $(80.5 \mathrm{~km}$.) north of the Gulf of Alaska, from which it is separated by a coastal plain and a series of lofty mountain ridges culminating in Mt. St. Elias, r8,008 ft. $(5500 \mathrm{~m}$.). Owing to this high barrier, the environment of the upper Seward Glacier is more continental than coastal. Orographic snowline is approximately $3000 \mathrm{ft} .(915 \mathrm{~m}$.$) , and the developed$ firn limit lies at about the same elevation on the lower Seward Glacier.

Measurements of firn temperature were all made at the Airstrip Station (see Fig. I) about 3 miles $(4.8 \mathrm{~km}$.) west of the eastern border of the upper Seward Glacier. This station is situated on the gently undulating firn surface at elevation $5^{875} \mathrm{ft}$. (1791 m.). The firn here extends to a depth of at least $60 \mathrm{ft}$. $(18.3 \mathrm{~m}$.) overlying approximately $2200 \mathrm{ft}$. $(67 \mathrm{I} \mathrm{m}$.) of ice as indicated by seismic reflections.

\section{OCCASION OF INVESTIGATION}

Opportunity to pursue a program of glaciological studies on the Seward-Malaspina glacier system was provided by project "Snow Cornice" sponsored by the Arctic Institute of North America and led by Walter A. Wood. Glaciological work was supported by the Office of Naval Research, the American Alpine Club, and the California Institute of Technology. Transport to the upper Seward Glacier was provided by the Arctic Institute's Norseman plane, equipped with ski-wheel landing gear and based at Yakutat airfield, 60 airline miles $(96 \cdot 5 \mathrm{~km}$.) to the south. Glaciological investigations covered the periods of 1o July-29 August 1948 and 15 June-29 August 1949 .

The assistance of all members of project "Snow Cornice" is acknowledged, and special appreciation is expressed to George P. Rigsby and Laurence H. Nobles who participated directly in the temperature studies. None of this work would have been possible without the wholehearted aid of project director Walter A. Wood. Temperature measurements made in March $195^{\circ}$ by Mr. Wood are included here through his courtesy. The manuscript has been improved by suggestions from A. E. J. Engel.

\section{EQUIPMENT}

Through the generous cooperation of the Pyrometry Laboratory, National Bureau of Standards (U.S.A.), use was obtained of the temperature-measuring equipment manufactured for the United States Antarctic Expedition 1939-41.7 This consisted of 18 thermohms, each of $100 \mathrm{ohms}$ resistance, and a balanced Wheatstone bridge calibrated to read temperatures directly. A detailed description of the equipment has been published in this Journal. ${ }^{8}$ Thermohms may not be as accurate as thermocouples, ${ }^{9}$ but they are easier to operate owing to elimination of an ice-water mixture for submergence of the standard junction of a thermocouple. Tests of the Wheatstone bridge by a standard coil and of the thermohms by submergence in an ice-water mixture show that the temperatures recorded are accurate to $\pm 0 \cdot 1^{\circ} \mathrm{C}$. Some less accurate measurements were made 
by liquid thermometers inserted directly into the walls of freshly dug pits in the Seward firn, but they were largely incidental.

Sverdrup's 10 experience led him to the conclusion that bored or punched holes of small diameter are more satisfactory for installation of electrical thermometers than the floors or walls of pits subsequently refilled with snow or firn. The pit itself disturbs the thermal regime, and the material used for a filling is usually wet firn which constitutes a large and abnormal source of heat. Equally important is the disturbance of stratification and ice layers within the firn and the disruption of their influence on melt water circulation. The British Jungfraujoch Party had more success with pits, ${ }^{11}$ probably because they were refilled with dry cold firn.

Small diameter holes were employed in the Seward firn. These were punched mechanically to depths of $\mathrm{I} 0 \mathrm{ft}$. to $25 \mathrm{ft}$. $(3 \mathrm{~m} .-7 \cdot 6 \mathrm{~m}$.) with $\mathrm{I}$ in. $(2.54 \mathrm{~cm}$.) aluminium pipe, and were extended to $204 \mathrm{ft}$. $(62 \cdot 2 \mathrm{~m}$.) by thermal boring which produced a hole about $\mathrm{r} \cdot 5 \mathrm{in} .(3 \cdot 8 \mathrm{~cm}$.) in diameter.

The thermal boring apparatus consisted of a portable generator, an electrical hot point, drill pipe, and a conducting cable (Fig. 2, p. 49I). The generator, a war-surplus item, weighed ro5 pounds $(47.6 \mathrm{~kg}$.) and was driven by a small two-cycle gasoline engine. It delivered 28.5 volts at 70 amperes, D.C. This low voltage permitted use of the drill pipe as one of the conductors, but the extremely heavy cable required to reduce energy loss in the other conductor was a distinct disadvantage. A system with higher voltage is desirable. The hot point was a 24 volt electrical heating coil enclosed in a cylindrical brass tube $\mathrm{I} \cdot 25$ in. $(3 \cdot 2 \mathrm{~cm}$.) in diameter and $\mathrm{II}$ in. $(28 \mathrm{~cm}$.) long, closed at one end and threaded on to the drill pipe at the other with a waterproof joint. The conducting cable extended down inside the drill pipe.

This equipment functioned satisfactorily and holes much deeper than $204 \mathrm{ft} .(62 \cdot 2 \mathrm{~m}$.) could have been bored had they been required and had additional pipe and cable been available. Thermal boring appears to be a wholly practicable means of penetrating glaciers, provided rocks embedded in the ice are not encountered, and Perutz ${ }^{12}$ has now bored a hole $446 \mathrm{ft}$. ( $136 \mathrm{~m}$.) deep by this method. Rate of penetration by thermal boring on the upper Seward Glacier varied considerably owing to stratification of the firn and to ice layers encountered. The average boring rate to $64 \mathrm{ft}$. depth (19.5 m.) was 7.5 in. ( $19 \mathrm{~cm}$.) per minute. Below 64 feet penetration dropped to a nearly constant rate of $\mathrm{I}_{4} \cdot 4$ in. $(3 \cdot 6 \mathrm{~cm}$.) per minute.

\section{Procedure}

In 1948.-Owing to unavoidable delays connected with the expedition plane, the first thermohms were not in operation until 12 July 1948 , and the entire task of installation was not completed until i7 July. Shallow holes were punched mechanically, but holes deeper than ro ft. $(3 \mathrm{~m}$.) were bored thermally. Thermohms were set in the bored holes after they had been plugged and left to stabilize for I -3 days. Installations were made at the following depths in feet: $3 \cdot 4$, * $6 \cdot 7,9 \cdot 6,13 \cdot 2,15 \cdot 7,20 \cdot 3,23 \cdot 9,30 \cdot 6,39 \cdot 4,61 \cdot 7,75,188$, and 204 . These figures decreased a few inches during the period of observation owing to lowering of the surface by ablation. A small amount of loose firn was sprinkled into the hole to form a packing around the thermohm and to close it off from possible convection currents. The top of the hole was plugged with rock wool. Court 13 outlines a highly idealized procedure for temperature measurements in polar ice to which the above conforms in part.

In 1949.-As in 1948 , initiation of temperature measurements was delayed approximately one month beyond the projected date by transportation troubles. Thermohms were installed and a consistent program of daily observations was started on 28 June (Fig. 3, p. 49r). Holes to a depth of $25 \mathrm{ft}$. $(7 \cdot 6 \mathrm{~m}$.) were punched mechanically, only the deeper holes were bored thermally. Small pellets of rock wool were sent down each hole to form a packing around and above the thermohm and to cut off convection currents within the hole. A plug of rock wool was established nearer

\footnotetext{
- In meters these depths are: $1 \cdot 06,2 \cdot 4,2 \cdot 93,4 \cdot 03,4 \cdot 8,6 \cdot 2,7 \cdot 3,9 \cdot 3,12 \cdot 1,18 \cdot 8,22 \cdot 9,57 \cdot 5,62 \cdot 2$.
} 
the surface, and the rest of the hole was filled with rock wool and covered by firn (Fig. 4, p. 482). The rock wool sent to the bottom of the hole did not seriously disturb thermal conditions, for all thermohms, save the one at $16 \mathrm{ft}$., displayed stabilized temperatures within 24 hours after installation. In 1949 thermohms were set at the following depths in feet: $4 \cdot 1, * 6 \cdot 2,9 \cdot 0,12 \cdot 3,14 \cdot 1,16 \cdot 0$, $2 \mathrm{I} \cdot 2,25^{\circ} \circ, 27 \cdot 0,3 \mathrm{I} \cdot 0,38 \cdot 8,42 \cdot 0,5 \mathrm{I} \cdot 0,6 \mathrm{I} \cdot 8$, and $72 \cdot 0$. All were installed on 27 June, except those at $4 . \mathrm{I}$ and $6 \cdot 2 \mathrm{ft}$. which were set on $28 \mathrm{June}$ and those at $\mathrm{I} 4 \cdot \mathrm{I}, 25^{\circ} \mathrm{O}$ and $3 \mathrm{I} \cdot 0 \mathrm{ft}$. which were installed on 2 July, when a further check was desired on certain parts of the temperature curve outlined by observations to that date. The above depths decreased $3^{\circ} \cdot 9$ in. $\left(9^{\cdot} 9 \mathrm{~cm}\right.$.) by surface ablation between 28 June and 8 July.

\section{RESUlts}

In 1948.-Owing to the unavoidably late date at which thermohms were installed, no measurements of the winter's chilled layer were obtained. All temperatures to a depth of $204 \mathrm{ft}$. $(62 \cdot 2 \mathrm{~m}$. $)$ were recorded as $0^{\circ} \pm 0.1^{\circ} \mathrm{C}$. as limited by the accuracy of the instruments. The work of $194^{8}$ served only to demonstrate the suitability of the equipment, to give experience in procedure, and to show that the winter's chilled layer had been ameliorated by mid-July. This established the Seward as a temperate glacier ${ }^{14}$ with temperatures at the pressure-melting point to at least $204 \mathrm{ft}$. $(62 \cdot 2 \mathrm{~m}$.) depth and presumably to its base.

In 1949.-Plans to initiate temperature measurements by middle or late May came to naught owing to difficulties of transportation, and it was 28 June before a consistent program of observations was started. Daily measurements were made until 9 July at which time it was apparent that the winter's chilled layer had been eliminated, at least in the vicinity of the Airstrip Station. The setting and environment of the Airstrip are reasonably representative for most of the upper Seward Glacier, and it is unlikely that any large area of the Seward firn differed by more than a week or two from the Airstrip in attaining a melting temperature. By contrast, on the Mönchfirn in the Alps the winter's chilled layer was ameliorated at points only a few hundred yards apart on dates differing by as much as $5^{\circ}$ days. This is attributed 15 largely to variations in the supply and movement of melt water within the firn.

The lowest temperature recorded by thermohms in the Seward firn was $-\mathbf{I} \cdot \mathbf{I}^{\circ} \mathrm{C}$. This was registered on 28 June at $2 \mathrm{I} \cdot 2 \mathrm{ft}$. depth $(6 \cdot 5 \mathrm{~m}$.). At that time the top of the chilled layer lay between 12 and $14 \mathrm{ft}$. $(3 \cdot 7-4 \cdot 3 \mathrm{~m}$.) beneath the surface, and the bottom was between 42 and $5 \mathrm{I} \mathrm{ft.} \mathrm{(12.8-}$ $15.5 \mathrm{~m}$.). Measurements with a liquid thermometer in a pit some ro days earlier gave firn temperatures as low as $-1 \cdot 5^{\circ} \mathrm{C}$. and showed the top of the chilled layer to be within 4 or $5 \mathrm{ft}$. $(\mathrm{r} \cdot 2-$ $\mathrm{I} \cdot 5 \mathrm{~m}$.) of the surface.

Results of thermohm observations are best summarized by Fig. 5 (p. 483), which shows that warming of the firn at this stage was relativeiy rapid and highly irregular. The top of the chilled layer descended, but the bottom remained fixed in so far as location of thermohms permits a conclusion. Noteworthy was the fact that some thermohms were warmed more rapidly than those immediately above and below. The winter's chilled layer disappeared between 7 and 8 July.

In 1950.-Walter A. Wood collected the temperature data presented in Table I during a brief visit to the upper Seward Glacier in March 1950. These measurements were made to a depth of II ft. $(3.36 \mathrm{~m}$.) by thermometers inserted into the walls of a freshly dug pit. The mercury thermometer used was probably more accurate than the dial thermometer, and its readings are reliable to at least $0.5^{\circ} \mathrm{C}$.

\section{INTERPRETATIONS}

A question may be raised as to disturbance of firn temperatures by thermal boring. Judging from 1949 observations this has not been serious, for all thermohms became stable within 24 hours

- These depths in meters are: $1 \cdot 25,1 \cdot 89,2 \cdot 75,3 \cdot 75,4 \cdot 3,4 \cdot 9,6 \cdot 5,7 \cdot 6,8 \cdot 2,9 \cdot 5,11 \cdot 8,12 \cdot 8,15 \cdot 5,18 \cdot 8,22 \cdot 0$. 
TABLE I

Temperatures in Seward firn, 20 March 1950

\begin{tabular}{|c|c|c|c|}
\hline \multicolumn{2}{|c|}{ Depth } & \multirow{2}{*}{$\begin{array}{c}\text { Dial Thermometer } \\
{ }^{\circ} \mathrm{C} \text {. }\end{array}$} & \multirow{2}{*}{$\begin{array}{c}\text { Mercury Thermometer } \\
{ }^{\circ} \mathrm{C} .\end{array}$} \\
\hline Feet & Meters & & \\
\hline I & 0.3 & $-11 \cdot 5$ & $-I I \cdot 2$ \\
\hline 2 & 0.61 & $-12 \cdot 0$ & -13.0 \\
\hline 3 & 0.92 & $-12 \cdot 0$ & $-12 \cdot 8$ \\
\hline 4 & $1 \cdot 22$ & $-11 \cdot 2$ & $-1 x \cdot 2$ \\
\hline 5 & $1 \cdot 53$ & -10.5 & -10.0 \\
\hline 6 & $x \cdot 83$ & -10.0 & $-9 \cdot 2$ \\
\hline 7 & $2 \cdot 14$ & -9.5 & $-8 \cdot 5$ \\
\hline 8 & $2 \cdot 44$ & $-9 \cdot \mathbf{x}$ & -8.0 \\
\hline 9 & $2 \cdot 75$ & $-8 \cdot 6$ & -7.4 \\
\hline 10 & 3.05 & $-8 \cdot I$ & Material too hard for \\
\hline II & 3.35 & $-7 \cdot 8$ & insertion of thermometer. \\
\hline
\end{tabular}

except the one $\mathrm{I} 6 \mathrm{ft}$. deep $(4.9 \mathrm{~m}$.) which, after installation on 27 June, recorded falling temperatures from 28 to 30 July before attaining stability. This could have been caused by an excessive amount of the melt water developed by boring being held in the firn surrounding this thermohm.

Firn can be warmed by conduction-convection from the atmosphere, by penetration and absorption of radiation, and by refreezing of percolating water derived largely by surface thawing but also supplied by rain. Heating by compaction is so small that it can be ignored, ${ }^{16}$ but heat generated by friction between shifting grains in settling firn might be more significant. In cold environments such as Antarctica 17 and central Greenland 18 where melt water does not form, the firn is warmed principally by conduction and radiation. Early deductions 19 concerning thermal conditions in glaciers apply best to this situation, but even in more temperate areas warming must occur principally by conduction and radiation until surface thawing occurs or rain falls.

When the surface of the firn is thawed, conduction from the atmosphere to deeper levels ceases because the thawed layer remains constantly at $0^{\circ} \mathrm{C}$. and heat conduction cannot occur without a temperature gradient. ${ }^{20}$ Many observations indicate that radiation does not penetrate snow and firn to depths greater than I meter, ${ }^{21 a}, b, c$ so its effects as a heating agent are limited. This leads to the conclusion that in areas where surface thawing is common the principal means of warming the firn at depth is by downward percolation and refreezing of melt water. The heat carried by the melt water is of course simply latent heat of fusion, for the water temperature remains at $\circ^{\circ} \mathrm{C}$. The soundness of this concept has been demonstrated previously, 22a, $b$ and data from the Seward firn offer further support.

In the period between 28 June and 8 July remnants of the winter's chilled layer in the Seward firn were destroyed entirely. This amelioration is more rapid and more irregular than appears possible by conduction, which, in fact, was precluded by the existence of an isothermal surface layer no less than $12-14 \mathrm{ft}$. $(3 \cdot 7-4 \cdot 3 \mathrm{~m}$.) thick. Behavior of the thermohm at $2 \mathrm{r} \cdot 2 \mathrm{ft} .(6 \cdot 5 \mathrm{~m}$. $)$ is instructive with regard to irregularity of the amelioration. On 28 June this thermohm marked the crest of a bulge on the curve of negative sub-surface temperatures (Fig. 5). By 2 July a distinct indentation of this bulge had developed, and by 3 July the thermohm at $2 \mathrm{I} \cdot 2 \mathrm{ft}$. was recording temperatures higher than those immediately above and below. By 4 July it had reached the melting point, although thermohms on either side still recorded sub-zero temperatures. A reasonable explanation is that larger amounts of melt water were freezing in the vicinity of the thermohm at $21.2 \mathrm{ft}$. $(6.5 \mathrm{~m}$.) than in firn layers above and below. This water probably moved in laterally from a near-by spot of deeper melt water penetration, either by capillarity along a fine-grained layer or a crust as suggested by Seligman 23 or by flow along the top of an impervious layer. 


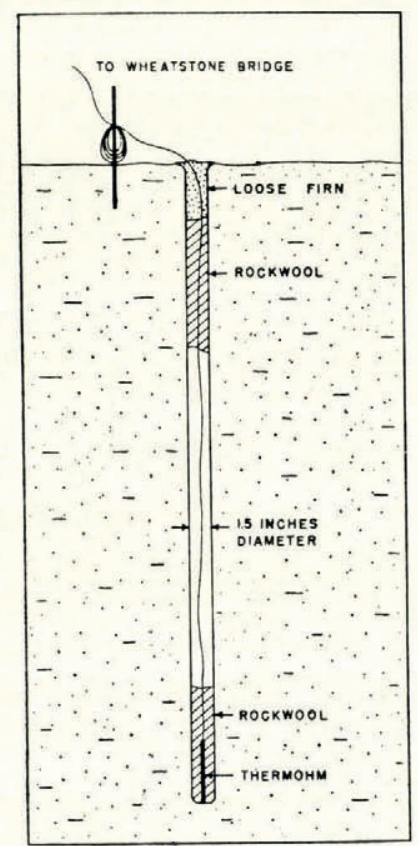

Fig. 4. Thermohm as installed in firn in 1949

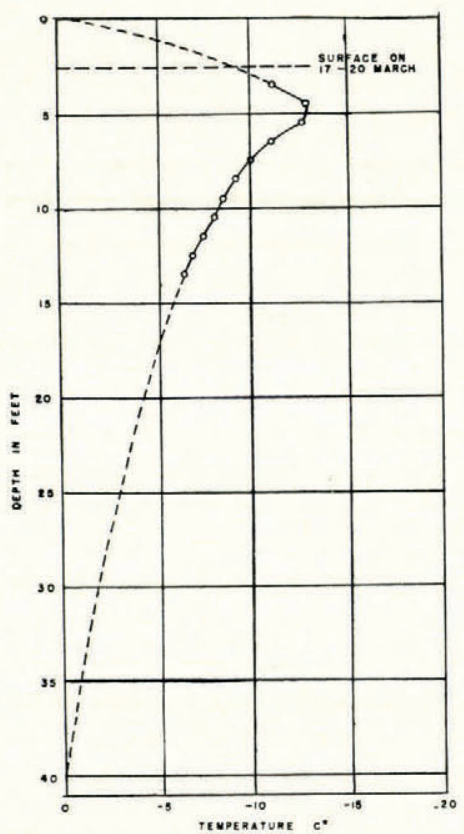

Fig. 6. Quasi-hypothetical curve for chilled layer of 1949-50 based on temperature measurements of I8-20 March I950, by Walter A. Wood

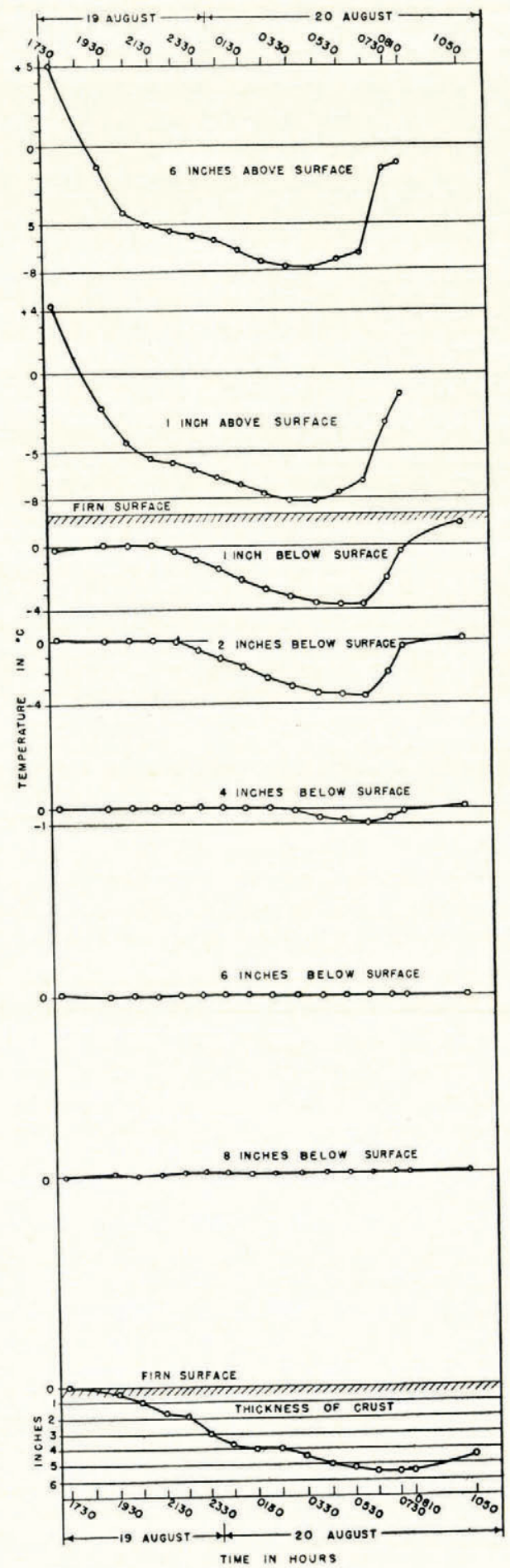

Fig. 8. Variation of temperature with depth during diurnal chilling of firn, $19-20$ August 1949 

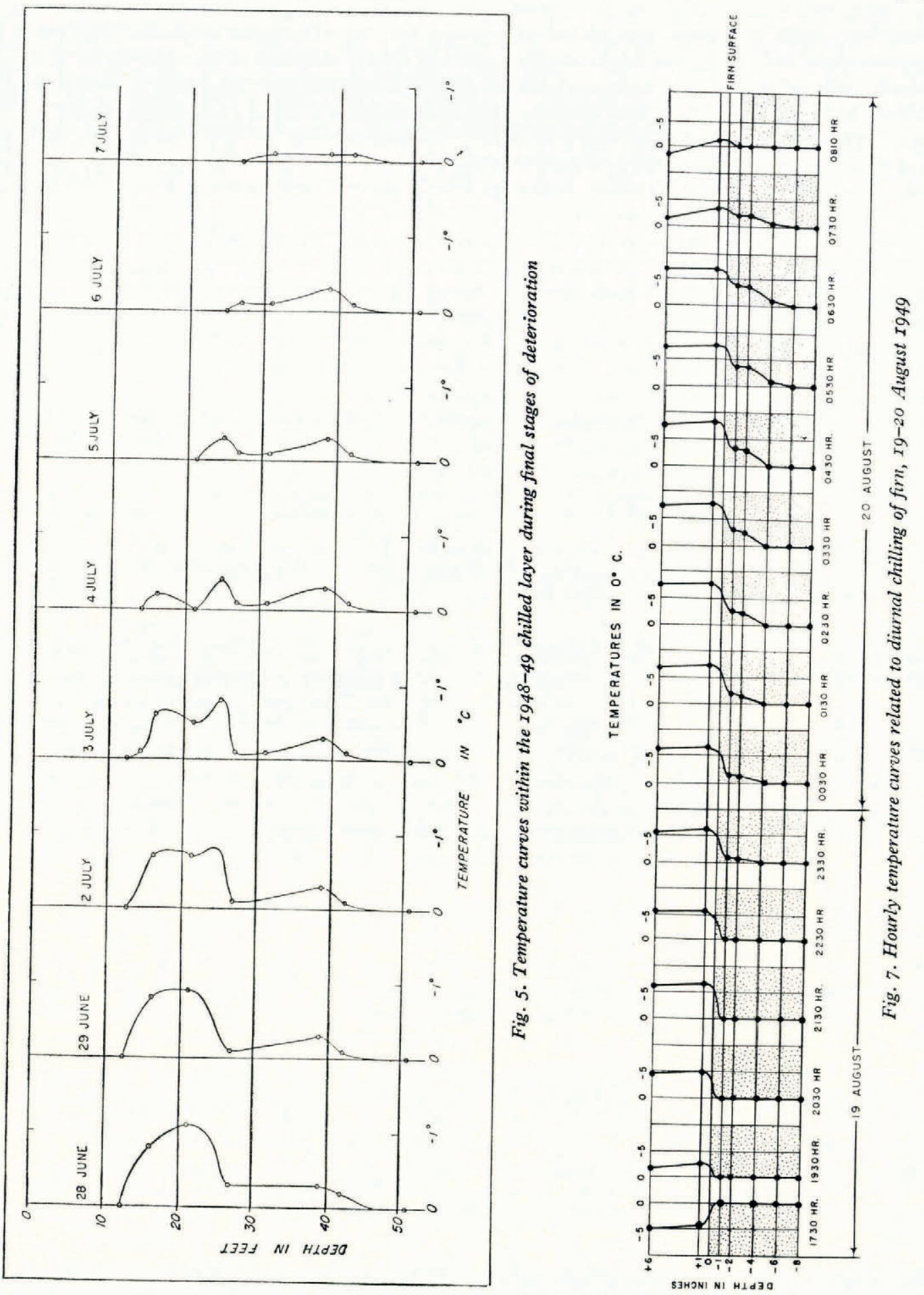
The temperature curves (Fig. 5) also show that deterioration of the chilled layer was much more rapid on and after 3 July than prior to that date. This behavior closely parallels ablation which was erratic and of limited amount prior to 3 July but became exceptionally heavy from that day on. This is exactly the relation to be expected if melt water is the chief cause of temperature amelioration in the firn.

Melt water exerts such a powerful influence on firn temperatures that it is entirely possible for bodies of firn in areas with mean annual atmospheric temperatures below freezing to have the thermal regimen of a temperate glacier because of the warming influence of melt water developed in summer. This has been demonstrated in the Alps 24 and North-East Land $25 a, b$ and is a matter overlooked in earlier generalizations. ${ }^{26}$ The thermal regimen of firn in areas devoid of melt water will differ markedly from that of firn in environments producing melt water.

At its full development the temperature curve in the Seward firn is not a straight or gently curving line extending from a minimum at the surface to the melting point at $40-50 \mathrm{ft}$. (12.2$15.3 \mathrm{~m}$.) depth. Instead, it has a distinct bulge of minimum temperature several feet below the surface. This comes about because the surface of the firn continues to rise through additional falls of snow after the atmospheric temperature curve turns upward. As the season advances into late spring and early summer, new snow accumulates under rising temperatures, so the upper layers are warmer than underlying layers which accumulated during winter. Transfer of heat by conduction within the firn will occur but probably not enough to eliminate this bulge in the temperature curve.

The $1948-49$ chilled layer peretrated the Seward firn to a depth between 42 and $5^{1} \mathrm{ft}$. ( $12 \cdot 8$ and $15.5 \mathrm{~m}$.). This is about in the middle of the 1o-20 meter range reported from other areas. ${ }^{27 a, b, c, d}$ Unfortunately, meteorological data from which the minimum temperature developed in the Seward firn might be calculated $28 a, b$ are not available. However, plotting and projecting of the firn temperatures obtained by Walter Wood in March $195^{\circ}$ produce a curve (Fig. 6, p. 482) thought to approximate the shape and magnitude of the winter's chilled layer for 1949-50. From this curve it appears that the chilled layer will be close to $40 \mathrm{ft}$. (12.2 m.) thick, and the minimum temperature of about $-13^{\circ} \mathrm{C}$. will lie 4 or $5 \mathrm{ft}$. $(\mathrm{I} \cdot 22-\mathrm{I} \cdot 53 \mathrm{~m}$.) below the surface. On the basis of the preceding discussion $-13^{\circ} \mathrm{C}$. is probably the lowest temperature that will be attained by the chilling of $1949-50$, and layers of snow subsequently deposited above che surface of March 20 will have higher temperatures. From Wood's data it appears that the upturn toward higher temperatures had occurred prior to 20 March $195^{\circ}$. These extrapolations are consistent with the shapes of known temperaiure curves, $29 a, b$ with the thickness of the chilled layer developed in $1948-49$, and with the additional accumulation to be expected in $195^{\circ}$.

The average temperature of the $1949-50$ chilled layer, $40 \mathrm{ft}$. $\left(12 \cdot 2 \mathrm{~m}\right.$.) thick, will be $-4.75^{\circ} \mathrm{C}$. If the mean bulk density of this $40 \mathrm{ft}$. of f.rn is approximately 0.70 , as suggested by earlier density measurements to a depth of $50 \mathrm{ft}$., its specific heat will be approximately $0.35 \mathrm{cal} . / \mathrm{cm} .{ }^{3}$. Assuming that the warming of this firn to $\circ^{\circ} \mathrm{C}$. is produced wholly by freezing of melt water, approximately $25.3 \mathrm{~cm}$. of water will be required, and this can be supplied by melting $50.6 \mathrm{~cm}$. of firn of bulk density 0.50 . This gives a rough indication of the amount of ablation that will have occurred at the time the winter's chilled layer is eliminated in case direct measure of ablation has not been possible. It illustrates one of the many uses to which information on temperature conditions in the firn can be put.

\section{THERMAL RELATIONS OF DIURNAL CRUSTS ON FIRN}

\section{INTRODUCTORY StATEMENT}

On almost every clear night during summer, a crust several inches thick formed on the surface of the Seward firn. It disappeared during the following day except in late summer when lower 
air temperatures and reduced radiation failed to produce complete disintegration. The development and deterioration of these diurnal crusts reproduce on a small scale the history of the winter's chilled layer, and brief study of thermal conditions associated with diurnal crusts was undertaken for this reason. It was subsequently discovered that Sverdrup ${ }^{30}$ made almost identical studies in western Spitsbergen with essentialiy the same results.

\section{Procedure}

Preliminary observations were made on the night of I0-1I August 1949 in order to establish procedure. Data from this trial are not complete and will not be cited except to indicate that they support the conclusions derived from later observations. The cold clear night of $19-20$ August 1949 was selected for more complete observations. Thermohms were set at $\mathrm{I}$ and 6 in. $\left(2 \cdot 5\right.$ and $\mathrm{I}_{5} \cdot \mathbf{2} \mathrm{cm}$.) above the firn and at $1,2,4,6$, and 8 in. $(2 \cdot 5,5 \cdot 1,10 \cdot 2,15 \cdot 2,20 \cdot 3 \mathrm{~cm}$.) below the surface. Thermohms above the firn were shaded from direct solar radiation, and those beneath the surface were shielded by narrow white cards. Previous studies $31 a, b$ indicate that protection from radiation is required, and the errors introduced by shading and shielding are minor compared to errors from a lack of protection. Temperatures were also read at the regularly established thermometer station $5^{2}$ in. ( $132 \mathrm{~cm}$.) above the firn. Hourly readings were started at $17.30 \mathrm{hr}$. on 19 August and continued until $08.10 \mathrm{hr}$. on 20 August. Supplementary observations were made at less frequent intervals to $16.50 \mathrm{hr}$. 20 August.

\section{Results}

Data obtained from these observations are compiled in Table II (p. 486). The shape of the temperature curve at hourly intervals is plotted in Fig. 7 (p. 483). Highlights of the thermal behavior are as follows. The lowest temperature recorded at the thermometer box, $5^{2}$ in. $(132 \mathrm{~cm}$.) above the surface, was $-6 \cdot 7^{\circ} \mathrm{C}$. at $04.3 \circ \mathrm{hr}$. on 20 August. The above-surface thermohms also recorded their minima at this time, these being $-7 \cdot 8^{\circ} \mathrm{C}$. at 6 in. $\left(15 \cdot 2 \mathrm{~cm}\right.$.) and $-8 \cdot 2^{\circ} \mathrm{C}$. at $\mathrm{I}$ in. $(2 \cdot 5 \mathrm{~cm}$.) above the surface. The minimum temperature was established at progressively later times at successively greater depths beneath the surface (Fig. 8, p. 482). The thermohm at depth 4 in. $(10 \cdot 2 \mathrm{~cm}$.) reached the minimum 2 hours later than the thermohms above the surface, so the rate of penetration of the minimum-temperature front was about 2 in. $(5.1 \mathrm{~cm}$.) per hour under the conditions of this observation. The degree of chilling also decreased with depth, being only $0.9^{\circ} \mathrm{C}$. at 4 in. $\left(10.2 \mathrm{~cm}\right.$.) compared to $3.7^{\circ} \mathrm{C}$. at I in. $(2.5 \mathrm{~cm}$.). The rate of decrease in chilling is thus roughly $0.9^{\circ}$ C. per inch. Sverdrup 32 obtained comparable records in Spitsbergen. The crust formed during the night of $19-20$ August on the Seward firn attained its maximum thickness, $5.5 \mathrm{in}$. ( $14 \mathrm{~cm}$.), about I hour after the thermohm at depth 4 in. ( $10 \cdot 2 \mathrm{~cm}$.) recorded its minimum (Fig. 8).

The rise of sub-surface temperatures on the morning of 20 August proceeded rapidly downward from the surface but did not attain the speed observed by Sverdrup in Spitsbergen where the chilled layer was brought to $0^{\circ} \mathrm{C}$. in 30 minutes. In the Seward firn, the first upturn in temperature occurred between 06.30 and $07.30 \mathrm{hr}$., and some traces of chilling remained at 08 . Io hr. However, all temperatures probably reached the melting point by $08.30 \mathrm{hr}$., so more than $\mathrm{I}$ but less than 2 hours were required for complete eradication of the chilling. Since 8 or more hours are required for development of this chilled layer by conduction, its amelioration in $\mathbf{1}-\mathbf{2}$ hours requires the work of some other factors, presumably melt water and absorption of penetrating radiation, a conclusion previously reached by Sverdrup. ${ }^{33}$

The fact that the lowest air temperatures were recorded closest to the surface suggests that cooling of the firn occurs in large part by outgoing radiation and possibly to some degree by evaporation. This is also indicated by the formation of a thin incipient crust on thawed firn between $\mathbf{1 6 . 0 0}$ and $17.00 \mathrm{hr}$. in the afternoon of clear days before the sun had set and while air temperatures 
$5^{2}$ in. $\left(1_{2} \mathrm{~cm}\right.$.) above the surface were still above freezing. The crust formed on the night of 19-20 August reached its maximum thickness between 06.00 and $07.00 \mathrm{hr}$. on 20 August, and, even though temperatures were brought to $\circ^{\circ} \mathrm{C}$. by $08.3 \circ \mathrm{hr}$., this crust preserved some of its strength and integrity below the surface throughout the entire day. Other observations indicate

TABLE II

Temperatures within Diurnal Crust on Firn, 19-20 August $1949^{*}$

\begin{tabular}{|c|c|c|c|c|c|c|c|c|c|c|c|}
\hline \multirow[b]{2}{*}{ Time } & \multirow[b]{2}{*}{$\begin{array}{c}\text { Thermometer } \\
52 \text { in. (1 } 32 \mathrm{~cm} .) \\
\text { above surface } \\
\text { C. }\end{array}$} & \multicolumn{7}{|c|}{ Thermohy Temperatures ${ }^{\circ} \mathrm{C}$. } & \multirow{2}{*}{\multicolumn{3}{|c|}{$\begin{array}{c}\text { Thickness of } \\
\text { crust }\end{array}$}} \\
\hline & & $\begin{array}{l}6 \text { in. } \\
(15 \cdot 2 \\
\text { cm. }) \\
\text { above } \\
\text { surface }\end{array}$ & $\begin{array}{c}\text { I in. } \\
(2.5 \mathrm{~cm} .) \\
\text { above } \\
\text { surface }\end{array}$ & $\begin{array}{c}\text { I in. } \\
(2.5 \mathrm{~cm} .) \\
\text { below } \\
\text { surface }\end{array}$ & $\begin{array}{c}2 \mathrm{in} . \\
(5 \cdot \mathrm{I} \mathrm{cm} .) \\
\text { below } \\
\text { surface }\end{array}$ & $\begin{array}{c}4 \text { in. } \\
(10.2 \\
\text { cm.) } \\
\text { below } \\
\text { surface }\end{array}$ & $\begin{array}{c}6 \text { in. } \\
(15 \cdot 2 \\
\text { cm. }) \\
\text { below } \\
\text { surface }\end{array}$ & $\begin{array}{c}8 \text { in. } \\
(20 \cdot 3 \\
\text { cm. }) \\
\text { below } \\
\text { surface }\end{array}$ & & & \\
\hline 17.30 & $2 \cdot 8$ & $5 \cdot 2$ & $4 \cdot 3$ & -0.2 & 0.1 & 0.1 & 0.2 & 0.0 & in. & race & $\mathrm{cm}$. \\
\hline I 9.30 & 0.0 & $-\mathrm{I} \cdot 3$ & $\begin{array}{r}43 \\
-2 \cdot 2\end{array}$ & 0.1 & 0.0 & 0.1 & 0.0 & 0.1 & 0.5 & . & I 3 \\
\hline 20.30 & $-3 \cdot 3$ & $-4 \cdot 2$ & $-4 \cdot 4$ & 0.1 & 0.1 & 0.1 & 0.1 & 0.0 & $I \cdot O$ & .. & $2 \cdot 5$ \\
\hline $21 \cdot 30$ & $-4 \cdot 4$ & -5.0 & -5.4 & 0.1 & 0.1 & 0.1 & 0.0 & $O \cdot I$ & I. 75 & $\cdots$ & $4 \cdot 4$ \\
\hline 22.30 & $-4 \cdot 4$ & -5.4 & -5.7 & -0.3 & 0.0 & 0.1 & 0.1 & $O \cdot I$ & I.9 & . & $4 \cdot 8$ \\
\hline $23 \cdot 30$ & -5.6 & -5.7 & $-6 \cdot 2$ & -0.9 & -0.6 & 0.2 & $O \cdot I$ & 0.2 & 3.0 & . & $7 \cdot 6$ \\
\hline 00.30 & $-5 \cdot 6$ & -6.0 & $-6 \cdot 6$ & $-\mathrm{I} \cdot 5$ & $-\mathbf{I} \cdot \mathbf{I}$ & 0.1 & 0.1 & 0.1 & 3.75 & $\ldots$ & $9 \cdot 5$ \\
\hline 01.30 & $-6 \cdot 1$ & $-6 \cdot 6$ & $-7 \cdot 1$ & $-2 \cdot I$ & $-I \cdot 7$ & 0.1 & 0.1 & 0.1 & 4.0 & $\ldots$ & 10.2 \\
\hline 02.30 & $-6 \cdot 7$ & $-7 \cdot 3$ & $-7 \cdot 7$ & $-2 \cdot 7$ & $-2 \cdot 4$ & 0.1 & 0.1 & 0.1 & 4.0 & . & 10.2 \\
\hline 03.30 & $-7 \cdot 2$ & $-7 \cdot 7$ & $-8 \cdot 1$ & $-3 \cdot 2$ & -2.9 & -0.2 & 0.1 & 0.1 & $4 \cdot 5$ & $\cdots$ & $I: 4$ \\
\hline 04.30 & $-7 \cdot 8$ & $-7 \cdot 8$ & $-8 \cdot 2$ & $-3 \cdot 6$ & $-3 \cdot 3$ & -0.6 & 0.1 & 0.1 & 5.0 & . & $12 \cdot 7$ \\
\hline 05.30 & -6.7 & $-7 \cdot 2$ & $-7 \cdot 6$ & -3.7 & -3.4 & -0.7 & 0.1 & 0.1 & $5 \cdot 25$ & . & 1 $3 \cdot 3$ \\
\hline 06.30 & $-6 \cdot 7$ & -6.9 & $-6 \cdot 9$ & -3.7 & $-3 \cdot 5$ & -0.9 & 0.1 & 0.1 & $5 \cdot 5$ & $\ldots$ & 14.0 \\
\hline 07.30 & -2.8 & $-I \cdot 5$ & $-3 \cdot I$ & -2.0 & -2.0 & -0.6 & 0.1 & 0.1 & $5 \cdot 5$ & . & $14^{\circ} 0$ \\
\hline 08.10 & -0.6 & $I \cdot 2$ & $-1 \cdot 4$ & -0.3 & -0.4 & -0.2 & 0.1 & 0.1 & $5 \cdot 5$ & . & 14.0 \\
\hline 10.50 & 10.6 & - & - & 0.4 & 0.2 & 0.2 & 0.1 & 0.1 & $4 \cdot 5$ & $\cdots$ & I I 4 \\
\hline
\end{tabular}

* Temperatures of $+0 \cdot 1^{\circ} \mathrm{C}$. merely reflect idiosyncracies of individual thermohms and the limit of accuracy of the apparatus. Temperatures of $+0.2^{\circ} \mathrm{C}$. recorded at $17.30 \mathrm{hr}$. at $6 \mathrm{in}$. below the surface and at $23.3 \circ \mathrm{hr} .4$ and 8 in. apparatus. Temperatures of +0.2 . recorded at $17.30 \mathrm{hr}$. at 6 in. chilling by limited evaporation in late afternoon. The temperatures recorded at $\mathrm{I}$ and $6 \mathrm{in}$. above the surface at $\mathrm{r} 0.50 \mathrm{hr}$. and possibly at $17.30 \mathrm{hr}$. were probably influenced by radiation.

that grains within a crust maintain enough cementation, coherence and interlocking for the crust to bear the weight of a man on foot several hours after it becomes isothermal at $0^{\circ} \mathrm{C}$. The durability of the crust after the nocturnal chill has been eliminated depends largely upon its thickness and the intensity of the meteorological factors producing deterioration.

\section{Conclusions regarding Diurnal Chilling}

The significant points derived from study of diurnal crusts are as follows : (I) Crustal development is initiated as soon as the cooling by outgoing radiation and evaporation exceeds the warming by incoming radiation and conduction from the air. On clear days, this occurs on the upper Seward Glacier late in the afternoon while the sun is still shining on the firn and air temperatures several feet above the surface are well above freezing. (2) Owing to cooling of the firn by outgoing radiation and evaporation, air temperatures close to the surface are lower than at higher levels. (3) The minimum-temperature front penetrated the firn by conduction at an average rate of about 2 in. $(5.1 \mathrm{~cm}$.) per hour under the conditions of this observation. (4) The amplitude of temperature variations decreased with depth at a rate of about $0.9^{\circ} \mathrm{C}$. per inch. (5) The chilled layer was ameliorated rapidly in something less than 2 hours, presumably in large part by melt water and 
absorption of penetrating radiation. (6) Development and deterioration of the diurnal chilled layer duplicate on a small scale the history of the annual chilled layer. This tends to support conclusions previously drawn concerning the behavior of the annual chilled layer. Since penetration of the diurnal chilling continued at depth after air temperatures started to rise, it seems likely that the annual chilled layer continues to grow for some time after the atmospheric temperature curve has started upward in spring. A similar behavior is reported with regard to sea ice. ${ }^{34 a, b}$

MS. received 24 Fune $195^{\circ}$

\section{REF E R E N C E S}

1. Ahlmann, H. W:son. Glaciological research on the North Atlantic coasts. Royal Geographical Society, Research Series No. I, I948, p. 66

2. Sverdrup, H. U. The temperature of the firn on Isachsen's Plateau, and general conclusions regarding temperature of the glaciers on West-Spitsbergen. Geografiska Annaler, Vol. 17, Ht. 1-2, 1935, p. 53-88.

3. Hughes, T. P. and Seligman, Gerald. The temperature, melt water movement, and density increase in the névé of an alpine glacier. Royal Astronomical Society, Monthly Notices, Geophysical Supplement, Vol. 4, No. 8, 1939, p. 616-34.

4. (a) Chamberlin, T. C. A contribution to the theory of glacial motion. University of Chicago, Decennial Publications, ist Series, Vol. 9, 1904, p. 196-200. (b) Chamberlin, T. C. and Salisbury, R. D. Geology. Vol. I-Geologic processes and their results. New York: Henry
Holt and Co., 1909, p. 273-79.

5. Drygalski, Erich v., and Machatschek, Fritz. Gletscherkunde, Enzyklopädie der Erdkunde. Vienna: Deuticke, 1942, p. $84-85$.

6. Matthes, F. E. Glaciers, Chapt. V in Hydrology-Physics of the Earth, Vol. 9, New York: McGraw-Hill, 1942, p. 152 7. Wade, F. A. The physical aspects of the Ross Shelf Ice. Proceedings of the American Philosophical Society, Vol. 89 ,
No. I, 1945, p. I69-70.

8. - Sub-surface temperature measuring equipment. Fournal of Glaciology, Vol. r, No. 2, 1947, p. 73-74.

9. Court, Arnold. Temperature measurements in polar ice. Fournal of Glaciology, Vol. 1, No. 5, 1949, p. 228.

Io. Sverdrup. Ref. 2, p. $53,59$.

11. Hughes and Seligman. Ref. 3, p. 619.

12. Perutz, M. F. Direct measurement of the velocity distribution in a vertical profile through a glacier. Fournal of Glaciology, Vol. I, No. 7, 1950, p. 382-83.

13. Court. Ref. 9, p. 227-30.

14. Ahlmann. Ref. r, p. 66

15. Hughes and Seligman. Ref. 3, p. 622, 625 .

16. Drygalski and Machatschek. Ref. 5, p. 83 .

17. Wade. Ref. 7, p. 167 .

18. Sorge, Ernst. The scientific results of the Wegener expeditions to Greenland. Geographical fournal, Vol. 81, 1933, p. 339 .

19. Chamberlin. Ref. 4

20. Sverdrup. Ref, 2, p. 7 I.

21. (a) Ibid.

(b) Gerdel, R. W. Penetration of radiation into the snow pack. Transactions, American Geophysical Union, Vol. 29, 1948, p. 370 .

(c) Work, R. A. Snow-layer density changes. Transactions, American Geophysical Union, Vol. 29, I948, p. 543.

22. (a) Sverdrup. Ref. 2, p. 7I.

(b) Hughes and Seligman. Ref. 3, p. 622-26.

23. Seligman, Gerald. Snow structure and ski fields. London: Macmillan, 1936, p. 278-80.

24. Hughes and Seligman. Ref. 3, p. 634 . 25. (a) Glen, A. R. The Oxford Úniversity Arctic expedition, North East Land, 1935-36. Geographical Journal, Vol. 90 ,
Nos. $3-4,1937$, p. 220-21.

(b) Moss, Robert. The physics of an ice-cap. Geographical fournal, Vol. 92, No. 3, 1938, p. 222.

26. Chamberlin. Ref. 4 (a), p. 198, 1904; 4 (b), p. 274, 1909.

27. (a) Sverdrup. Ref. 2, p. 54 .

(b) Hughes and Seligman. Ref. 3, p. 622.

(c) Wade. Ref. 7, p. 169 .

(d) Sorge. Ref. 18, p. 339 .

28. (a) Hughes and Seligman. Ref. 3, p. 626-3I.

(b) Sverdrup. Ref. 2, p. $76-78$

29. (a) Ref. 2, p. 70.

(b) Hughes and Seligman. Ref. 3, p. $621-26$.

30. Sverdrup. Ref. 2, p. 82-87.

31. (a) - Ref. 2, p. 82 .

(b) Gerdel. Ref. 21, p. 366.

32. Sverdrup. Ref. 2, p. 84

33. - Ref. 2, p. 86-87.

34. (a) Low, A. P. Report on the Dominion Government expedition to Hudson Bay and the Arctic Islands on board the D.G.S. Neptune, 1903-1904, Ottawa, 1906, p. 86-87.

(b) Bernier, J. E. Report on the Dominion of Canada government expedition to the Arctic islands and Hudson Strait on board the D.G.S. Arctic, Ottawa, 1910, p. 343 . 


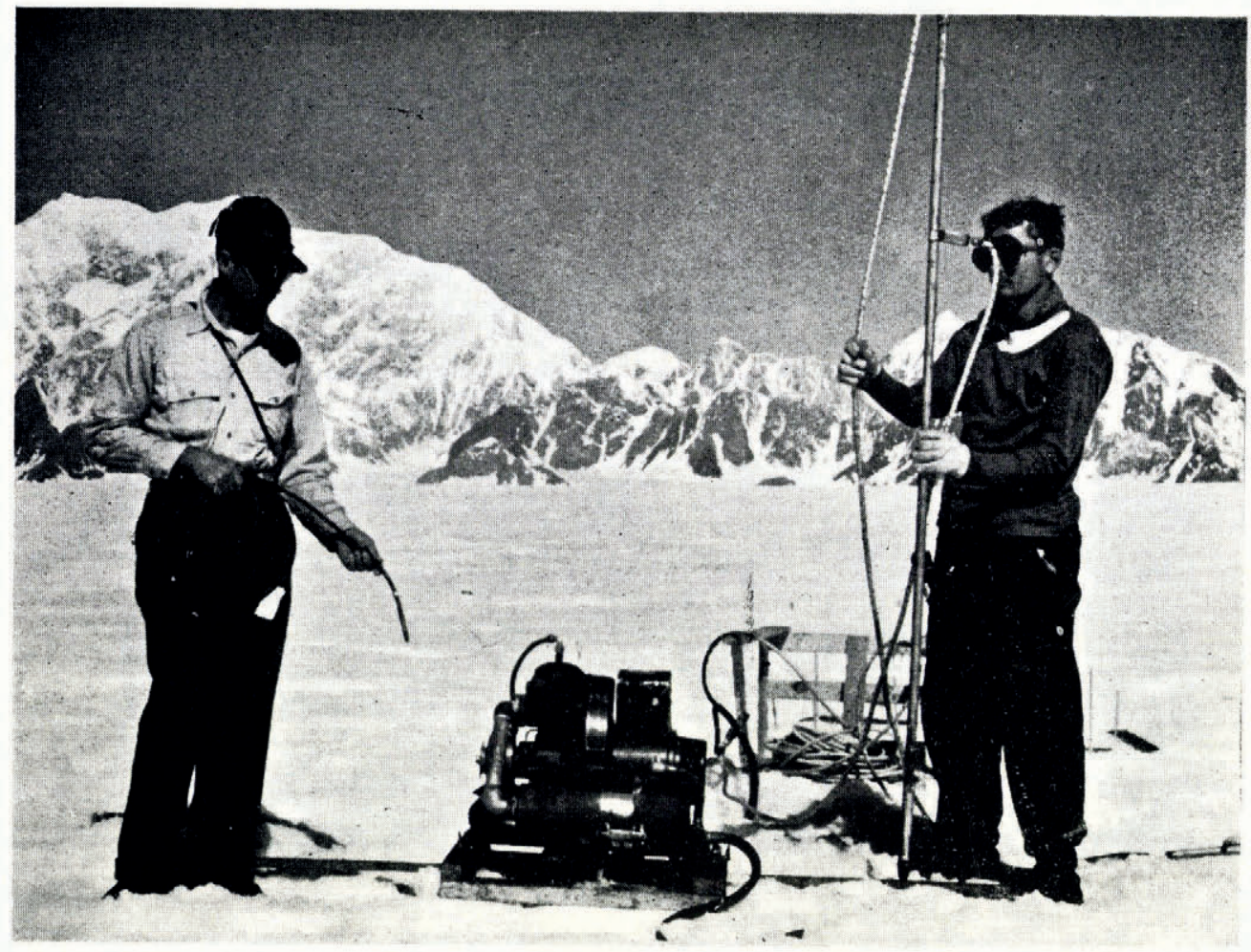

Fig. 2. Thermal boring equipment. Man at left holding thermohm (see text, p. 479)

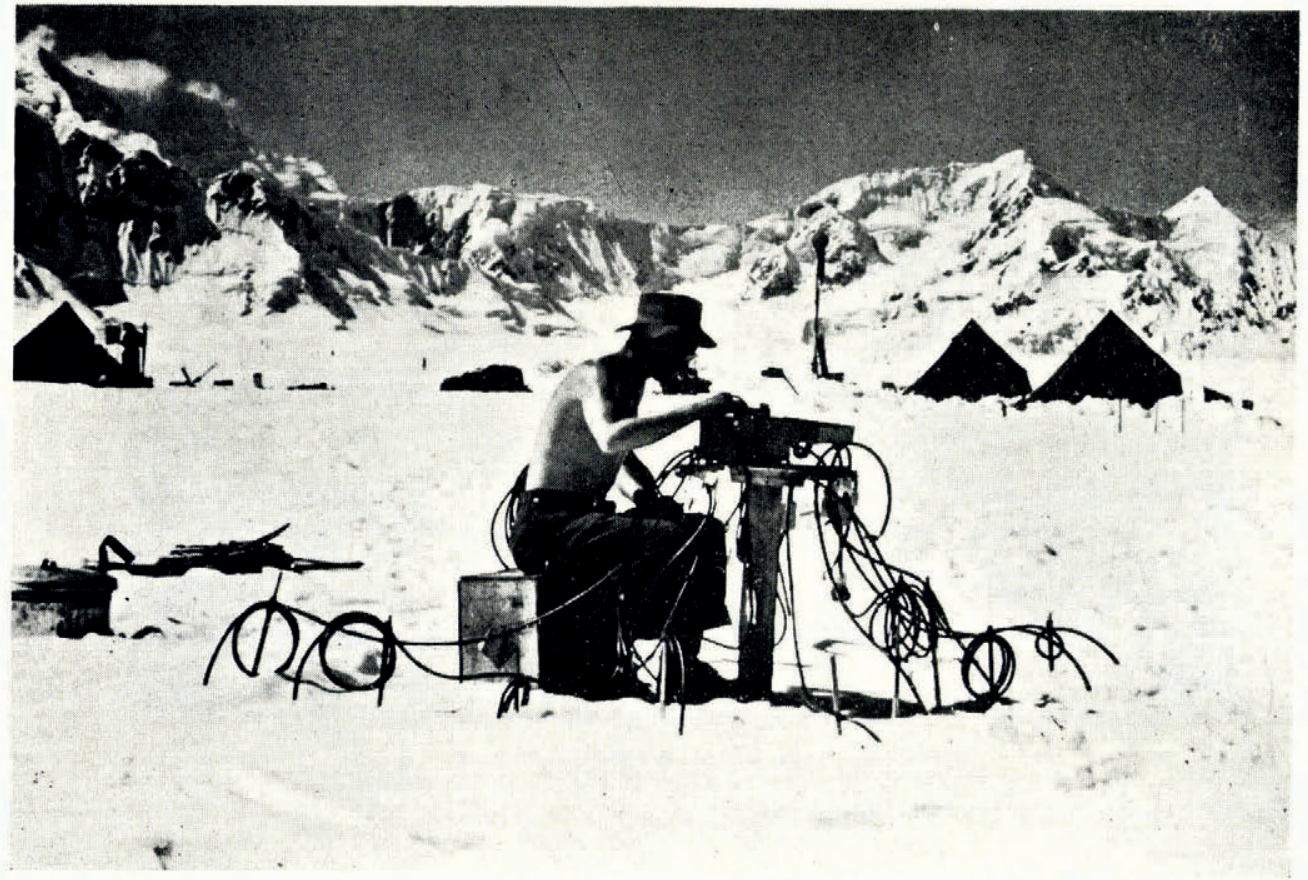

Fig. 3. Temperature-measuring equipment as installed at Airstrip Station on the upper Seward Glacier (see text, p. 479) 